\section{Leisure-time physical activity among women in a neighbourhood in Bogotá, Colombia: prevalence and socio-demographic correlates}

\author{
Estudo de prevalência e fatores associados \\ com exercício físico em mulheres de uma área \\ urbana de Bogotá, Colômbia
}

Luis Fernando Gómez 1

Julio Cesar Mateus 1,2

Gustavo Cabrera 1,3

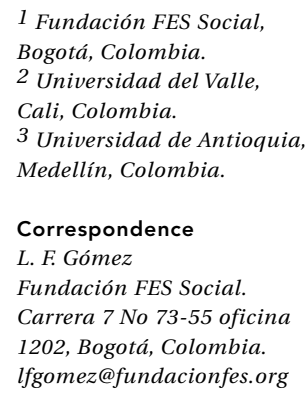

\begin{abstract}
This study measured the prevalence of leisuretime physical activity in women from 18 to 69 years of age and identified correlated social factors in the neighborhood of Santafe, Bogotá, Colombia. Levels of physical activity were calculated through a population survey $(n=1,045)$. Logistic regression modeling identified factors associated with inactivity. Some $79.1 \%$ of respondents reported being inactive; $15.7 \%$ practiced physical exercise irregularly; and 5.2\% regularly practiced physical exercise. After adjustment of covariates, physical inactivity was associated with not participating in recreational weekend activities on Sundays and not planning to lose weight. The results of this study show the high proportion of physically inactive women in a community in Bogotá Intervention strategies should be developed to reinforce recreational weekend activities on promoted by the Municipality.
\end{abstract}

Physical Activity; Women's Health; Urban Health

\section{Introduction}

Despite the evidence of the health benefits of regular physical activity, sedentary lifestyle is a growing problem in urban societies $1,2,3,4,5,6$. According to several studies, women are less active than men, and this has been related to reproductive as well as social factors such as poverty, low education, caregiving duties, belonging to minority communities, and lack of social support 7,8,9,10,11,12. In addition, cultural characteristics of Latin American women may influence physical activity patterns 13 . Such aspects may be more pronounced at earlier stages in the adoption of physical exercise 14 . According to a qualitative study by Juarbe et al. 15 , for Latina women residing in the United States, perceived benefits and barriers are competing elements related to physical inactivity.

Despite the public health importance of physical activity in women, there is little information on its social correlates in Latin American cities. The cultural characteristics of this region require further analysis, taking the social roles of Latin American women into account.

The issue has special relevance for the Santafe neighborhood of Bogotá for two basic reasons. First, Santafe has the city's highest incidence of coronary heart disease. Second, as in other neighborhoods of Bogotá, several streets and avenues are closed off to motor vehicle traffic on Sundays so that pedestrians and cy- 
clists can engage in weekend recreational activities 16 . This program has been termed the Ciclovía (Bicycle Path) by the Municipal government 17.

The objectives of this study were to identify the levels of physical activity and socio-demographic factors associated with leisure-time physical inactivity among women 18 to 69 years of age in the Santafe neighborhood, Bogotá, Colombia. The results of this study may foster technical recommendations for the development of health policies to promote physical activity for women in Latin American cities.

\section{Methods}

\section{Study design and population characteristics}

The ethics committee of this study reviewed and approved the protocol and the different procedures for measurement.

Santafe has a population of $103,904(61.4 \%$ 18 to 69 years) and is located in the center of Bogotá. Some $96.4 \%$ of the residents belong to lower-middle and low-income strata.

The Santafe study was a baseline cross-sectional study aimed at determining the prevalence of cardiovascular risk factors in this urban district, including leisure-time physical activity, prior to community interventions designed to promote healthy lifestyles. The study is a component of the CARMEN Program (in English: Joint Actions for Multi-factorial Reduction of Noncommunicable Disease), which is the Latin American adaptation of CINDI (Countrywide Integrated Noncommunicable Disease Intervention). 18

\section{Survey design and measurement}

A multistage probability survey was administered from May to August 2002 in 1,045 non-institutionalized women aged 18 to 69 years from the urban neighborhood of Santafe. These survey methods have been described in detail elsewhere and are discussed only briefly here 19 .

Data were collected through the administration of a questionnaire, which was structured from the recreation, sports, and leisuretime physical activity component of the long version of IPAQ (International Physical Activity Questionnaire) 20.

A structured interview was administered to selected persons. Independent variables included age, marital status, schooling, principal activity in the last 30 days, participation in the Ciclovia program, and self-perceived health.
For the prevalence rates and logistic analysis, we decided to collapse the variable "principal activity in the last 30 days" into a new variable called "having caregiving duties".

The outcome variable was the level of leisure-time physical activity in the last seven days, categorized as inactive, irregularly active, or regularly active, taking into account the following criteria defined by under the CELAFICS consensus (Centro de Estudos do Laboratório de Aptidão Física de São Caetano do Sul) 21.

- "Inactive" adults are those who never engage in any moderate or vigorous leisure-time physical activity for as long as 10 minutes at a time.

- "Regularly active" adults engage in moderate or vigorous leisure-time physical activity for 30 minutes a day in cumulative spans of at least 10 minutes on 5 or more days a week; or in vigorous leisure-time physical activity for 20 minutes per session on 3 or more days a week. - "Irregularly active" adults engage in moderate or vigorous leisure-time physical activity for as long 10 minutes at a time, but do not meet the other criteria for regularly active individuals.

\section{Statistical analysis}

Prevalence rates were determined by selected characteristics. Descriptive statistics were used to identify the distribution of different physical activity levels according to the independent variables included in this study.

To determine the factors associated with sedentary lifestyle, we used a logistic regression analysis following the Hosmer \& Lemeshow criteria 22 . Due to the complex survey design, regression analysis was adjusted for cluster effect and sample weightings for unequal probabilities of selection. These analyses were performed with the Stata Statistical Software.

\section{Results}

\section{Sample characteristics}

Participation in the study was $97 \%$, involving 1,045 women with a median age of 37.2 years, distributed in the following age groups: 405 from 18 to 29 years, 476 from 30 to 49 , and 164 from 50 to 69 . Other selected characteristics are shown in Table 1.

\section{Leisure-time physical activity prevalence}

Some $79.1 \%$ of respondents reported being inactive, $15.7 \%$ irregularly active, and $5.2 \%$ regularly active. The highest prevalence rates of 
physical inactivity were in women ages 50 to 69 (84.0\%), widows (86.7\%), those with incomplete primary school (86.5), and those who reported poor self-perceived health $(91.7 \%)$, no intention of losing weight (82.6\%), caregiving duties $(81.8 \%)$, and no participation in the weekend recreational program known as Ciclovía $(85.2 \%)$ (Table 2). We identified significant differences by age, schooling, self-perceived health, caregiving duties, intention of losing weight, and participation in Ciclovía.

\section{Correlates of physical inactivity}

Table 3 shows the crude and adjusted odds ratios for the associations between the various covariates and leisure-time physical inactivity. After adjustment for potential confounders, the odds of being inactive were higher in women 30 to 49 years of age, those who had no intention of losing weight, and those who had never participated in Ciclovía.

Women who reported caregiving duties had greater odds of being physically inactive in the crude model, but this association was not significant after adjustment.

In the case of schooling, we found an inverse and graded relationship in the crude model, with OR decreasing as educational levels increased. This association was not evident after adjusting for potential confounders.

A similar pattern, but in the inverse direction, was apparent for self-perceived health, which had a progressive and higher association with being inactive. Those with poor selfperceived health had the highest crude OR, followed by those with an average and good perception, respectively. In the adjusted model this association was not maintained, although the odds ratios maintained the same progression.

\section{Discussion}

Given that other neighborhoods in Bogotá share similar socioeconomic characteristics with Santafe, this study's findings could contribute to an analysis of sedentary lifestyle in the city as a whole, providing technical criteria for the development of interventions to promote physical exercise.

Overall, $79.1 \%$ of women from 18 to 69 years of age and residing in Santafe were inactive during their leisure time, thus highlighting the relevance of promoting physical exercise in this community. In comparison with our results, Gamez et al. 23 found in 1994 that $57 \%$ of women in Bogota were inactive during their
Table 1

Percentages of selected socio-demographic characteristics

of women participants. Santafe Study, 2002.

\begin{tabular}{|c|c|c|}
\hline \multirow[t]{2}{*}{ Variable } & \multicolumn{2}{|c|}{ Study sample } \\
\hline & $\mathrm{n}$ & $\%$ \\
\hline \multicolumn{3}{|l|}{ Age groups (years) } \\
\hline 18 to 29 & 405 & 38.8 \\
\hline 30 to 49 & 476 & 45.5 \\
\hline 50 to 69 & 164 & 15.7 \\
\hline \multicolumn{3}{|l|}{ Marital status } \\
\hline Single & 309 & 29.5 \\
\hline Married or living together & 586 & 56.1 \\
\hline Separated/divorced & 96 & 9.2 \\
\hline Widowed & 54 & 5.2 \\
\hline \multicolumn{3}{|l|}{ Principal activity in the last 30 days } \\
\hline Working & 456 & 44.9 \\
\hline Looking for work & 32 & 3.1 \\
\hline Studying & 31 & 3.1 \\
\hline Caregiving duties & 52 & 5.1 \\
\hline Others (retired, disabled or handicapped) & 445 & 43.8 \\
\hline Missing values & 29 & - \\
\hline \multicolumn{3}{|l|}{ Educational level } \\
\hline Primary school, incomplete & 201 & 19.2 \\
\hline Primary school, complete & 198 & 19.0 \\
\hline High school & 531 & 50.8 \\
\hline Higher education & 115 & 11.0 \\
\hline \multicolumn{3}{|l|}{ Self-perceived Health } \\
\hline Excellent or very good & 114 & 10.9 \\
\hline Good & 445 & 42.6 \\
\hline Fair & 438 & 41.9 \\
\hline Poor & 48 & 4.6 \\
\hline \multicolumn{3}{|l|}{ Intention of losing weight } \\
\hline Yes & 314 & 30.1 \\
\hline No & 731 & 69.9 \\
\hline \multicolumn{3}{|l|}{ Having caregiving duties } \\
\hline No & 600 & 57.4 \\
\hline Yes & 445 & 42.6 \\
\hline \multicolumn{3}{|l|}{ Participation in Ciclovía } \\
\hline Always or usually & 72 & 6.9 \\
\hline Sometimes & 297 & 28.4 \\
\hline Never & 676 & 64.7 \\
\hline
\end{tabular}


Aged-adjusted prevalence (with relative standard errors) of leisure-time physical activity levels by selected characteristics. Santafe Study, 2002.

\begin{tabular}{|c|c|c|c|}
\hline \multirow[t]{2}{*}{ Variable } & \multicolumn{3}{|c|}{ Leisure-time physical activity levels } \\
\hline & Regularly active & Irregularly active & Inactive \\
\hline All participants & $5.2(14.6)$ & $15.7(7.9)$ & $79.1(1.7)$ \\
\hline \multicolumn{4}{|l|}{ Age (years)* } \\
\hline $18-29$ & $6.5(20.8)$ & $23.0(10.0)$ & $70.5(3.5)$ \\
\hline $30-49$ & $4.4(23.7)$ & $127(13.3)$ & $82.9(2.3)$ \\
\hline $50-69$ & $4.5(30.1)$ & $11.5(20.1)$ & $84.0(3.2)$ \\
\hline \multicolumn{4}{|l|}{ Marital status } \\
\hline Single & $5.0(24.5)$ & $22.9(11.5)$ & $72.1(3.9)$ \\
\hline Married or living together & $4.8(20.1)$ & $13.3(11.7)$ & $819(2.1)$ \\
\hline Separated/divorced & $8.6(36.9)$ & $16.4(25.5)$ & $75.0(6.5)$ \\
\hline Widowed & $36(78.0)$ & $9.7(46.0)$ & $86.7(5.9)$ \\
\hline \multicolumn{4}{|l|}{ Educational level ${ }^{\star \star}$} \\
\hline Primary school, incomplete & $3.8(35.3)$ & $9.7(23.8)$ & $86.5(3.0)$ \\
\hline Primary school, complete & $2.7(47.3)$ & $14.5(19.1)$ & $82.8(3.5)$ \\
\hline High school & $6.8(17.8)$ & $17.3(10.5)$ & $75.9(2.7)$ \\
\hline Higher education & $4.7(43.0)$ & $26.9(17.0)$ & $68.4(7.0)$ \\
\hline \multicolumn{4}{|l|}{ Self-perceived health ${ }^{\star \star}$} \\
\hline Excellent or very good & $7.0(37.7)$ & $23.7(18.6)$ & $69.3(6.9)$ \\
\hline Good & $6.1(20.6)$ & $184(11.0)$ & $75.5(2.9)$ \\
\hline Fair & $4.6(23.9)$ & $14.1(12.9)$ & $81.3(2.5)$ \\
\hline Poor & $21(10.2)$ & $6.2(62.0)$ & $91.7(4.8)$ \\
\hline \multicolumn{4}{|l|}{ Intention of losing weight ${ }^{\star}$} \\
\hline Yes & $9.7(19.1)$ & $20.4(12.3)$ & $69.9(4.1)$ \\
\hline No & $3.2(22.5)$ & $14.2(10.0)$ & $826(1.8)$ \\
\hline \multicolumn{4}{|l|}{ Having caregiving duties ${ }^{\star \star}$} \\
\hline No & $6.2(17.2)$ & $18.7(9.4)$ & $75.1(2.6)$ \\
\hline Yes & $43(24.8)$ & $139(13.0)$ & $81.8(2.4)$ \\
\hline \multicolumn{4}{|l|}{ Participation in Ciclovía } \\
\hline Always or usually & $16.5(29.4)$ & $40.3(15.9)$ & $43.2(15.0)$ \\
\hline Sometimes & $5.8(25.9)$ & $23.1(11.7)$ & $71.1(4.1)$ \\
\hline Never & $3.8(32.3)$ & $110(18.3)$ & $85.2(2.6)$ \\
\hline
\end{tabular}

* $p<0.05$

$\star \star p<0.01$

leisure time. These differences may be due to the studies' sampling structures and classification patterns.

After adjusting for confounders, our findings also indicate that physical inactivity was associated with not planning to lose weight and not participating in the Ciclovía program. As for plans to lose weight, some authors have suggested that moderate overweight may be an important motivating factor for engaging in physical exercise 14 . This argument depends on the interrelation between body weight and the actual intention of losing weight.

Although the association between not participating in Ciclovía and physical inactivity was expected, this finding is relevant to the city of Bogotá Interpreting this inversely, women who reported that they always or usually participate in these activities were more active during their leisure time. The Ciclovía program mobilizes an important number of people belonging to different socioeconomic strata in 
Odds ratios of being physical inactive in leisure-time by selected characteristics: Santafe Study, 2002.

\begin{tabular}{|c|c|c|c|c|}
\hline Variable & Crude OR & $95 \% \mathrm{Cl}$ & Adjusted $\mathrm{OR}^{\star}$ & $95 \% \mathrm{Cl}$ \\
\hline \multicolumn{5}{|l|}{ Age (years) } \\
\hline $18-29$ (ref) & 1.00 & & 1.00 & \\
\hline $30-49$ & 2.76 & $1.25-2.49$ & 1.71 & $1.10-2.64$ \\
\hline $50-69$ & 1.99 & $1.17-3.37$ & 1.16 & $0.62-2.17$ \\
\hline \multicolumn{5}{|l|}{ Marital status } \\
\hline Single (ref) & 1.00 & & 1.00 & \\
\hline Married or living together & 1.75 & $1.21-2.51$ & 1.22 & $0.80-1.85$ \\
\hline Separated/divorced & 1.15 & $0.62-2.13$ & 0.75 & $0.36-1.56$ \\
\hline Widowed & 2.52 & $1.06-5.99$ & 1.61 & $0.64-4.08$ \\
\hline \multicolumn{5}{|l|}{ Educational levels } \\
\hline Primary school, incomplete & 1.00 & & 1.00 & \\
\hline Primary school, complete & 0.74 & $0.40-1.37$ & 0.87 & $0.46-1.66$ \\
\hline High school & 0.52 & $0.32-0.86$ & 0.74 & $0.39-1.38$ \\
\hline Higher education & 0.37 & $0.20-0.70$ & 0.74 & $0.34-1.58$ \\
\hline \multicolumn{5}{|l|}{ Self-perceived health } \\
\hline Excellent or very good & 1.00 & & 1.00 & \\
\hline Good & 1.36 & $0.77-2.40$ & 1.32 & $0.71-2.46$ \\
\hline Fair & 2.11 & $1.15-3.88$ & 1.69 & $0.83-3.43$ \\
\hline Poor & 3.45 & $1.07-11.04$ & 2.31 & $0.64-8.31$ \\
\hline \multicolumn{5}{|l|}{ Intention of losing weight } \\
\hline Yes & 1.00 & & 1.00 & \\
\hline No & 2.03 & $1.41-2.93$ & 2.23 & $1.49-3.34$ \\
\hline \multicolumn{5}{|l|}{ Having caregiving duties } \\
\hline No & 1.00 & & 1.00 & \\
\hline Yes & 1.44 & $1.01-2.06$ & 1.19 & $0.80-1.77$ \\
\hline \multicolumn{5}{|l|}{ Participation in Ciclovía } \\
\hline Always or usually & 1.00 & & 1.00 & \\
\hline Occasionally & 3.73 & $2.16-6.44$ & 3.55 & $1.90-6.61$ \\
\hline Never & 9.06 & $5.24-15.67$ & 7.41 & $3.98-13.79$ \\
\hline
\end{tabular}

* Odds ratios are adjusted for age categories, caregiving duties, educational levels, participation in Ciclovía, intention of losing weight, and marital status.

Bogotá, thus reinforcing regularly active individuals and serving as the primary opportunity for the irregularly active to engage in leisuretime physical exercise. This finding is not an evidence of the effect of Ciclovia, but only a descriptive association.

We did not find significant associations with educational level after adjustment for potential confounders. However, the crude OR for the schooling variable indicates a progressive reduction in physical inactivity as educational level increases. According to several authors, education as a marker for socioeconomic sta- tus has been identified as an important predictor of physical activity 6 . Individuals with more schooling and higher socioeconomic status may have more autonomy in their leisure time, which may also influence their exercise patterns. This hypothesis should be validated and characterized in our context through further research.

In the crude model, performance of caregiving duties was associated with leisure-time physical inactivity. After adjustment for potential confounders, this association did not remain, although the OR was preserved in the 
same direction. There is evidence that time restrictions due to caregiving duties and other family responsibilities could have an important effect on the problem in a community with high fertility rates 11,12 . The social and cultural characteristics of the Santafe district could tend to confirm this factor's relevance.

We found a progressive association between self-perceived health and leisure-time inactivity. This expected finding should be interpreted as a sign of internal validity of measurement in the dependent variable.

The principal limitation of this study is its cross-sectional design, which does not allow one to impute a causal relationship in the observed associations. In addition, the restricted study sample does not permit wider statistical inferences for the city as a whole. Finally, due to the participants' social roles, they may be physically active in areas other than leisuretime; in this sense, other dimensions should be explored, such as job-related activity, transportation patterns, and housework.

\section{Conclusion}

Despite the limitations just described, the study's findings highlight the problem of leisure-time physical inactivity in women residing in a low-income area of Bogotá. This situation may be present in other neighborhoods in the city that share similar cultural and social characteristics.

Our results can also provide useful information for policymakers to identify subgroups at risk within the overall female population in order to develop intervention strategies. Among the key factors, the fact that few women in this sample participated in weekend recreational activities such Ciclovía emphasizes the need to reinforce this kind of program.

\section{Resumo}

O estudo mediu a prevalência de exercício físico em mulheres de 18 a 69 anos de idade e identificou correlatos sociais no bairro de Santa Fé, em Bogotá, Colômbia. Os níveis de atividade física foram calculados por meio de um estudo populacional com uma amostra de 1.045 mulheres. Um modelo de regressão logística identificou fatores associados com sedentarismo. De acordo com os resultados, 79,1\% das mulheres foram classificadas como inativas; $15,7 \%$ relataram atividade física irregular e apenas $5,2 \%$ praticavam exercícios físicos regularmente. Após o ajuste das covariáveis, a inatividade física estava associada com a falta de participação em atividades dominicais de lazer e com a falta de planos para perder peso. Os resultados do estudo demonstram a alta proporção de mulheres fisicamente inativas numa comunidade de baixa renda de Bogotá. Estratégias de intervenção devem ser desenvolvidas para reforçar os exercícios físicos promovidos nas áreas de lazer reservadas aos domingos pelo governo municipal de Bogotá.

Atividade Física; Saúde da Mulher; Saúde Urbana

\section{Contributors}

L. F. Gómez led the design and drafting of the all sections in this paper, as well as the statistical analysis. J. C. Mateus contributed to the drafting of the all sections in this paper. G. Cabrera contributed to the drafting of the introduction and discussion.

\section{Acknowledgments}

The authors wish to thank Dr. Luis Carlos Gómez, who designed the study's sampling methodology; Jose Fernando Cardona, Julio Cesar Velazquez, and Gladis Espinosa, who provided valuable comments on earlier drafts of this manuscript. This study was funded by the Bogotá Municipal Health Department, Colombia. 


\section{References}

1. Powel KE, Thompson PD, Caspersen CJ, Kendrick JS. Physical activity and the incidence of coronary heart disease. Annu Rev Public Health 1987; 8:253-87.

2. Berlin JA, Colditz GA. A meta-analysis of physical activity in the prevention of coronary heart disease. Am J Epidemiol 1990; 132:612-28.

3. Morris JN, Everitt MG, Pollard R, Chave SP, Semmence AM. Vigorous exercise in leisure-time: protection against coronary heart disease. Lancet 1980; 2:1207-10.

4. Paffenbarger RS, Hyde RT, Wing AL, Hsieh CC. Physical activity, all-cause mortality and longevity of college alumni. N Engl J Med 1986; 314:605-13.

5. Blair SN, Kohl HW, Paffenbarger RS, Clark DG, Cooper HK, Gibbons LW. Physical fitness and allcause mortality. JAMA 1989; 262:395-401.

6. Stewart AL, King AC, Haskell WL. Endurance exercise and health-related quality of life in 50-65year-old adults. Gerontologist 1993; 33:782-9.

7. U.S. Department of Health and Human Services, Centers for Disease Control and Prevention. Physical activity and health. A report of the surgeon general. Washington DC: Centers for Disease Control and Prevention; 1996.

8. Bull FC, Eyler AA, King AC, Brownson RC. Stage of readiness to exercise in ethnically diverse women: a US survey. Med Sci Sports Exerc 2001; 33:114756.

9. Crespo CJ, Ainsworth BE, Keteyian SJ, Heath GW, Smit E. Prevalence of physical activity and its relation to social class in US adults: results from the Third National Health and Nutrition Examination Survey. Med Sci Sports Exerc 1999; 31:1821-7.

10. Eyler A, Brownson R, Donnatelle R, Brown D, Sallis J. Physical activity social support and middle and older-aged minority women: results from a US survey. Soc Sci Med 1999; 49:781-9.

11. Scharff DP, Homan S, Kreuter M, Brennan L. Factors associated with physical activity in women across the life span: implications for program development. Women Health 1999; 29:115-34.

12. Eyler AA, Matson-Koffman D, Vest JR, Evenson KR, Sanderson B, Thompson JL, et al. Environmental, policy, and cultural factors related to physical activity in a diverse sample of women: The Women's Cardiovascular Health Network Project. Women Health 2002; 36:123-34.
13. Evenson KR, Sarmiento OL, Macon L, Tawney KW, Ammerman AS. Enviromental, policy and cultural factors related to physical activity among Latina Immigrants. Women Health 2002; 36:43-57.

14. Sherwood NE, Jeffery RW. The behavioral determinants of exercise: implications for physical activity interventions. Annu Rev Nutr 2000; 20:21-44.

15. Juarbe T, Turok XP, Perez-Stable EJ. Perceived benefits and barriers to physical activity among older Latina women. West J Nurs Res 2002; 24:868-86.

16. Espinosa G. Mortalidad y morbilidad por enfermedades cardiocerebrovasculares y diabetes en Santafé de Bogotá. Boletín Epidemiológico Distrital 1998; 3:1-8.

17. Instituto Distrital de Recreación y Deportes, Alcaldía Mayor de Bogotá. Ciclovías. http://www.cicloruta.com/ciclovias/ (accessed on Nov/2002).

18. World Health Organization. Countrywide Integrated Non-communicable Diseases Intervention (CINDI) Program. Protocol and guidelines. Copenhagen: World Health Organization; 1995.

19. Secretaría Distrital de Salud de Bogotá. Estudio de línea de base para la evaluación del impacto de las acciones de prevención de factores de riesgo cardiovasculares en la localidad de Santafe. Bogotá: Fundación FES Social; 2003.

20. International Physical Study. International Physical Activity Questionnaire, 2002. http://www.ipaq. ki.se/ (accessed on Apr/2002).

21. Matsudo S, Matsudo V, Araújo T, Andrade D, Andrade E, Oliveira L, et al. Nível de atividade física da população do Estado de São Paulo: análise de acordo com o gênero, idade, nível sócio-econômico, distribuição geográfica e de conhecimento. Rev Bras Ciênc Mov 2002; 10:41-50.

22. Hosmer D, Lemeshow S. Applied logistic regression. Applied probability and statistics. New York: John Wiley \& Sons; 1989

23. Gámez R, Venegas AS, Barón HY, Pinto AM, Rodriguez AT. Conhecimento, percepção e nível de atividade física dos cidadãos de Santa Fé de Bogotá. Rev Bras Ciênc Mov 1999; 8:51-71.

Submitted on 12/Mar/2003

Final version resubmitted on 07/Mar/2003

Approved on 14/Nov/2003 